Vol. 20(2011): 262-268.

\title{
The main weed species and their control in oilseed crops in Finland
}

\author{
Jukka Salonen $^{1 *}$, Pauliina Laitinen ${ }^{1}$, Marketta Saastamoinen ${ }^{2}$ and Juha Salopelto ${ }^{3}$ \\ ${ }^{\prime}$ MTT Agrifood Research Finland, Plant Production Research, FI-31600 Jokioinen, Finland \\ ${ }^{2}$ Satafood Development Association, FI-32700 Huittinen, Finland \\ ${ }^{3}$ Hankkija Maatalous Ltd., FI-05801 Hyvinkää, Finland \\ *e-mail:jukka.salonen@mtt.fi
}

\begin{abstract}
A survey of weeds in spring-sown oilseed crops (Brassica rapa ssp. oleifera and Brassica napus ssp. oleifera) was conducted in southern and central Finland during 2007-2009, representing the first such extensive investigation in the country. The occurrence of the most abundant weed species in oilseeds was surveyed in 429 fields. In the fields with moderate or high weed infestation, 1-6 harmful weed species were recorded by visual observation according to their biomass production. About 40 weed species were recorded, the most predominant being Chenopodium album, Galeopsis spp., Galium spurium, Sonchus arvensis and Tripleurospermum inodorum. Elymus repens was the only major grass weed. Chemical weed control of broad-leaved weeds had been practised in $53 \%$ of the fields, resulting in relatively good control. In addition, both selective graminicides and glyphosate were used to control E. repens. Mechanical weed control was not practised in any field. The crop yield level was about $300 \mathrm{~kg} \mathrm{ha}^{-1}$ higher in the fields with low weed infestation compared with in the highly infested fields. New promising options to replace the banned herbicide trifluralin are available. Thus, the most harmful weeds, such as C. album, which interferes with the production of high-quality oil for human consumption, can still be effectively controlled.
\end{abstract}

Key-words: Brassica rapa ssp. oleifera L., Brassica napus ssp. oleifera L., herbicides, spring turnip rape, spring oilseed rape, trifluralin, weed flora, weed control, yield 
Vol. 20(2011): 262-268.

\section{Introduction}

Spring-sown cultivars of oilseed crops, predominantly turnip rape Brassica rapa ssp. oleifera, and to minor extent oilseed rape, Brassica napus ssp. oleifera, are commonly grown in Finland as far north as the central areas from $60^{\circ} \mathrm{N}$ to $65^{\circ} \mathrm{N}$. Harvested seed is mainly processed for food oils and the oilseed meal is used as a feed component. In addition, the use of oilseeds for biofuel is foreseen. Cultivation of oilseed crops has increased markedly during recent years, and they are considered to be excellent break-crops for cereal-dominated cropping systems (Peltonen-Sainio et al. 2009). The harvested area of oilseed crops in Finland ranged from 63800 ha to 89500 ha in 2007-2009 (FAOSTAT 2011). The interest in growing oilseed crops instead of spring cereals has been partly related to fluctuating grain prices over time, and the cultivated area of springsown oilseeds reached its record level, 158000 ha, in 2010 (TIKE 2010).

The long-term declining trend in the yields of oilseed crops in Finland has not been particularly encouraging (Peltonen-Sainio et al. 2007). Increased pressure by plant pathogens is assumed to be one of the major constraints to achieving yield potentials with modern high-yielding cultivars. Evidently a proportion of potential oilseed yield is also lost due to competition with weeds. The selection of herbicides for broad-leaved weed control in oilseed crops in Finland has been very limited and relatively expensive. Moreover, the most applied active ingredient, trifluralin, is not registered for use beyond 2009 as a result of the EU Commission decision 2010/355/EU to not include trifluralin on the list of marketable plant protection products. Trifluralin has been used because of its efficacy against the major weeds in spring-sown crops, such as Chenopodium album, Galeopsis spp. and Stellaria media.

This study was the first comprehensive survey of weeds in oilseed crops carried out in Finnish farmers' fields. The survey provides new information on the composition of weed floras in arable fields in Finland. Earlier sources of such information are the surveys in spring cereal fields (Salonen et al. 2001, Salonen et al. 2011) and field peas (Pis- um sativum L.) (Salonen et al. 2005). Reference surveys in oilseeds are available, for example, from Denmark (Andreasen \& Stryhn 2008), Germany (Goerke et al. 2008) and Slovak Republic (Týr \& Vereš 2010).

The objective of the study was to rank the most harmful weed species that currently interfere with oilseed cropping and to outline the current weed control options applied in practice. The survey information is needed to complement national weed mapping data, for advisory purposes and for demonstrating the need for updated control strategies.

\section{Material and methods Study regions, farms and fields}

The weed survey was carried out in southern and central Finland from $60^{\circ} \mathrm{N}$ to $63^{\circ} \mathrm{N}$ during 20072009. The survey regions and farms were selected randomly using national statistics on oilseed crop cultivation from previous years, which were provided by the Information Centre of the Ministry of Agriculture and Forestry. Information about the visited regions and oilseed cropping in general is reported in detail elsewhere (Peltonen-Sainio et al. 2011). The information on cropping measures was recorded by interviewing farmers. The questionnaire included, for example, information on crop variety, crop rotation, soil properties, tillage practices, herbicide use and estimated yield.

The number of fields examined in the weed survey was 144 in 2007, 155 in 2008 and 130 in 2009. In most cases just one field per farm was studied annually. All farms, except one, practiced conventional cropping. The previous crop in surveyed fields was predominantly (75\% of fields) a spring cereal (barley, oats or wheat).

\section{Weed samples and yield estimates}

The occurrence of weeds was visually assessed in August by walking through the entire field (or 
Salonen, J. et al. Weeds in oilseed crops in Finland

a representative part of a very large field) along a W-shaped route with 15-20 stops and recording the 1-6 most abundant weed species that appeared either evenly distributed or in patches. The main purpose of field tours was to carry out a crop disease survey and therefore the assessment method was selected according to sampling techniques relevant to estimation of disease incidence (Delp et al. 1986).

The level of weed infestation in each field, associated with visual estimation of weed biomass production, was categorized into three classes; 1) negligible_low, 2) moderate (including patchy occurrence) or 3) high. In the case of the field being put into the first class, no individual weed species were recorded. Thus, the results on particular weed species presented in this report derive either from the fields with moderate or high weed infestation. To ensure congruence in visual assessment of weed infestation, three survey teams exercised the sampling procedure and scaling before the annual field tour in late July, and the team members remained the same during the survey years.

Farmers estimated the harvested yields according to official procedures used e.g. by TIKE Information Centre of the Ministry of Agriculture and Forestry. Data on estimated crop yields were analysed using analysis of covariance, taking into account the following factors: year, crop, soil type, special soil properties, tillage, year since last cultivation of Brassica crops, incidence of clubroot and weed abundance ( 3 classes). The model was fitted using SAS/MIXED software.

\section{Results}

Some 40 species were recorded in the list of abundant species, many of them, however, occasionally in 1-5 fields only (Table 1). Galium spurium, Sonchus arvensis, Chenopodium album, Galeopsis spp. and Tripleurospermum inodorum were most often rated as abundant species in survey fields (Fig. 1). Elymus repens was the only grass species recorded.

The weed infestation was highest in 2007 when the oilseed fields suffered from a severe flea beetle
Table 1. Incidence of 38 weed species recorded in the fields rated as either "Moderate" or "High" weed infestation in a survey conducted in 2007-2009 in 429 springsown oilseed fields.

\begin{tabular}{|c|c|c|}
\hline No & Scientific name & $\begin{array}{l}\text { No. of } \\
\text { infested } \\
\text { fields }\end{array}$ \\
\hline 1 & Galium spurium L. & 112 \\
\hline 2 & Sonchus arvensis L. & 99 \\
\hline 3 & Chenopodium album L. & 81 \\
\hline 4 & Galeopsis L. spp. & 78 \\
\hline 5 & Tripleurospermum inodorum (L.) Sch. Bip & .73 \\
\hline 6 & Cirsium arvense (L.) Scop. & 58 \\
\hline 7 & Stellaria media (L.) Vill. & 29 \\
\hline 8 & Elymus repens (L.) Gould & 25 \\
\hline 9 & Fallopia convolvulus (L.) À. Löve & 13 \\
\hline 10 & Persicaria lapathifolia (L.) Gray & 10 \\
\hline 11 & Taraxacum officinale Weber in Wigg. & 7 \\
\hline 12 & Thlaspi arvense L. & 6 \\
\hline 13 & Artemisia vulgaris L. & 5 \\
\hline 14 & Matricaria matricarioides (Less.) Porter & 5 \\
\hline 15 & Polygonum aviculare L. & 5 \\
\hline 16 & Stachys palustris L. & 4 \\
\hline 17 & Stellaria graminea L. & 3 \\
\hline 18 & Viola arvensis Murray & 3 \\
\hline 19 & Centaurea cyanus L. & 2 \\
\hline 20 & Equisetum arvense $\mathrm{L}$. & 2 \\
\hline 21 & Fumaria officinalis L. & 2 \\
\hline 22 & Lamium purpureum $\mathrm{L}$. & 2 \\
\hline 23 & Lapsana communis L. & 2 \\
\hline 24 & Arabidopsis thaliana (L.) Heynh. & 1 \\
\hline 25 & Capsella bursa-pastoris (L.) Medik. & 1 \\
\hline 26 & Cardamine L. spp. & 1 \\
\hline 27 & Euphorbia helioscopia L. & 1 \\
\hline 28 & Myosotis arvensis (L.) Hill. & 1 \\
\hline 29 & Plantago major L. & 1 \\
\hline 30 & Polygonum L. spp. & 1 \\
\hline 31 & Raphanus raphanistrum $\mathrm{L}$. & 1 \\
\hline 32 & Rumex longifolius DC. & 1 \\
\hline 33 & Solanum tuberosum L. & 1 \\
\hline 34 & Spergula arvensis L. & 1 \\
\hline 35 & Trifolium hybridum L. & 1 \\
\hline 36 & Trifolium (L.) spp. & 1 \\
\hline 37 & Tussilago farfara L. & 1 \\
\hline 38 & Urtica dioica L. & 1 \\
\hline
\end{tabular}

${ }^{1)}$ Out of the 259 fields rated as either moderate or high weed infestation 
Vol. 20(2011): 262-268.

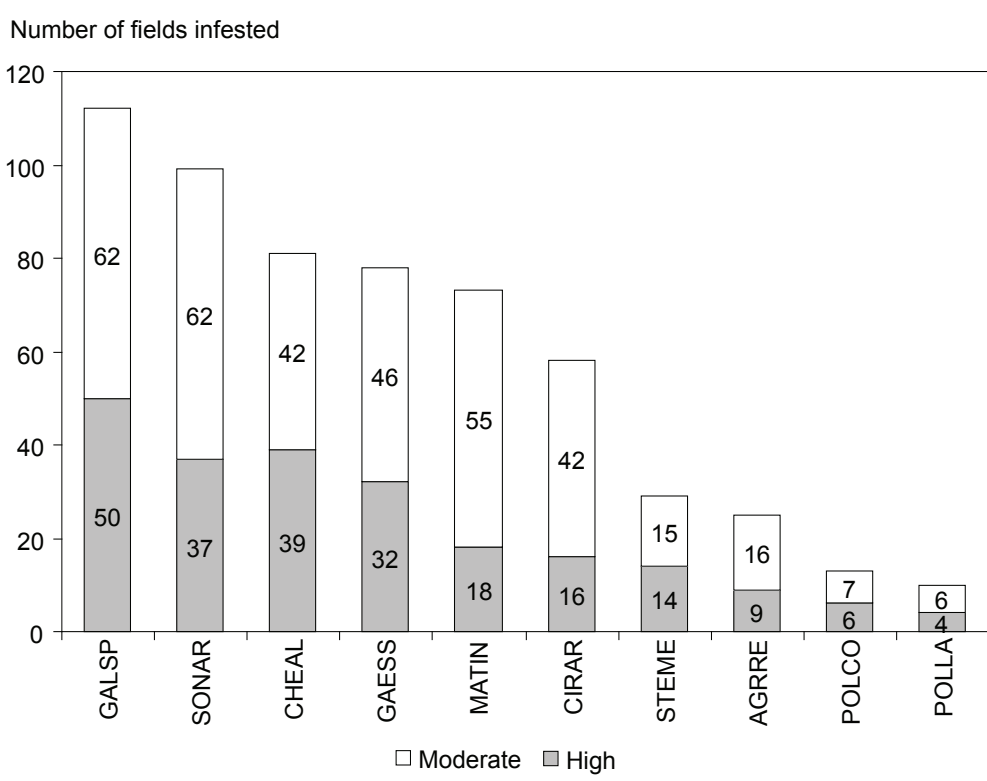

Fig. 1. Incidence of weed species in oilseed crops in 2007 2009. The number of fields where the weed species were recorded in the 259 fields rated as either "Moderate" or "High" infestation. Key to EPPO codes of weed species: GALSP=Galium spurium, $\mathrm{SONAR}=$ Sonchus arvensis, $\mathrm{CHEAL}=$ Chenopodium album, GAESS=Galeopsis spp., MATIN=Tripleurospermum inodorum, CIRAR $=$ Cirsium arvense, STEME=Stellaria media, AGRRE=Elymus repens, $\mathrm{POLCO}=$ Fallopia convolvulus, POLLA=Persicaria lapathifolia.
(Phyllotreta spp.) attack. Only $20 \%$ of surveyed fields were ranked as low-infestation in 2007 while the proportion of these 'weed-free' fields was about $55 \%$ and $45 \%$ in 2008 and 2009 , respectively. In total, there were 170 fields with negligible or low weed pressure. Their proportion was significantly $\left(\chi^{2}=31.77, \mathrm{df}=2, p<0.001\right)$ higher in the fields treated with herbicides compared with in the untreated fields (Fig 2).

Chemical weed control against broad-leaved weeds was practised on 53\% of fields. None of the survey farms practised mechanical weed control. Trifluralin was the most common active ingredient applied to total of 190 fields with an annual range of $41-53 \%$ of treated fields. Napropamide, metazachlor, clopyralid/picloram and imazamox were the other active ingredients used for this purpose.

In addition to the control of broad-leaved weeds, grass weeds, Elymus repens in particular, were controlled separately with selective graminicides, including propaquizafop, quizalofop-Pethyl, fluazifop-P-butyl and cycloxydim. However, selective grass weed control was a less common practice and was carried out only on 123 survey fields. Glyphosate had been applied to 47 fields either in the previous autumn or at sowing time, mainly in conjunction with direct drilling. Control had apparently been successful since almost

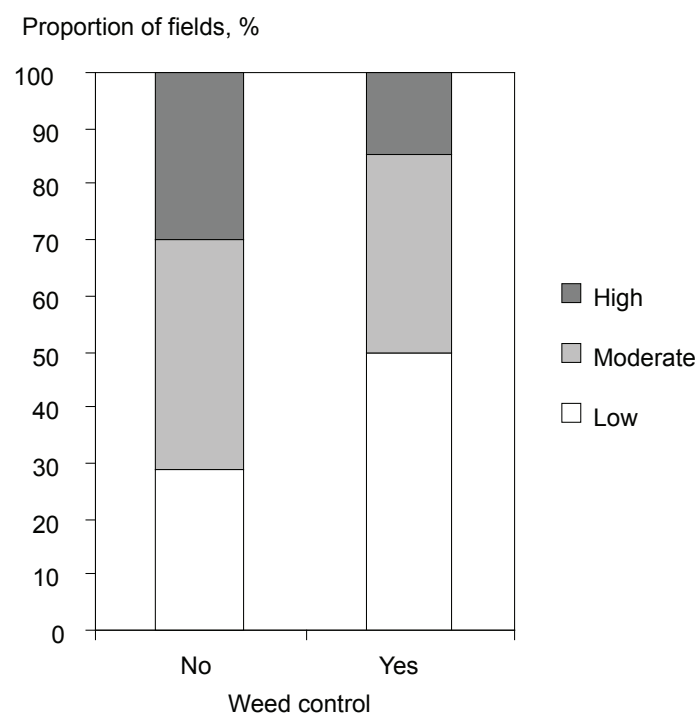

Fig. 2. Proportion of survey fields in three weed infestation classes as a result of either refraining from or relying on chemical control of broad-leaved weeds. 
Salonen, J. et al. Weeds in oilseed crops in Finland

all fields with moderate or high infestation of $E$. repens had not been treated with graminicides.

Based on the yield results estimated by farmers, the average yield in all three years was higher in the fields with low weed infestation compared with in the highly infested fields. Estimated yields were analyzed statistically and significant differences $(p<0.001)$ between weed infestation levels were detected; the average yield in the fields with low level infestation was $1853 \mathrm{~kg} \mathrm{ha}^{-1}(\mathrm{~N}=113$, s.e. 59), in moderately-infested fields $1703 \mathrm{~kg} \mathrm{ha}^{-1}$ $(\mathrm{N}=109$, s.e. 57) and in highly-infested fields 1551 $\mathrm{kg} \mathrm{ha}^{-1}(\mathrm{~N}=60$, s.e. 63$)$, respectively. The average crop yields were highest in the fields where both the broad-leaved and grass weeds had been controlled.

\section{Discussion}

The weed survey was part of a research project aimed at improving oilseed crop cultivation in Finland. The main purpose for farm visits in 2007-2009 was to collect crop samples for plant disease and root growth monitoring (Peltonen-Sainio et al. 2011). Therefore, the weed occurrence was observed in a less comprehensive manner compared with the earlier weed surveys carried out by MTT. However, the results from oilseed crop fields are applicable for comparison of the weed species producing the highest biomass, for example in spring cereals. As an example, tall perennial species such as Cirsium arvense, Elymus repens and Sonchus arvensis were naturally easy to observe in crop stands in August and therefore were often rated as abundant species when present in survey fields. In most cases, however, they occurred only in patches, as observed also in other surveys (e.g. Salonen et al. 2005, Goerke et al. 2007). All weed species were still relatively fresh and easy to observe at the time of the field tour in August.

The observed weed species, particularly the first ten species in the rank, are characteristic of arable fields in Finland where annual spring-sown crops, particularly spring cereals, dominate the crop rotations. The most abundant species, like Chenopodium album and Sonchus arvensis, have been among the most harmful species in spring cereals and in field peas (Salonen et al. 2001, Salonen et al. 2005). In contrast, some rare weed species in arable fields, like Arabidopsis thaliana, Centaurea cyanys and Euphorbia helioscopia, were ranked abundant in 1-2 fields, probably as a result of slow and uneven establishment of crop stand and/or refraining from chemical weed control.

There were no clear regional differences in the occurrence of weed species. The success of some species, like Galium spurium, is well in line with the latest observations from spring cereal fields (Salonen et al. 2011). G. spurium is a characteristic species of Finnish arable fields, whereas $G$. aparine prevails in oilseed crops in other countries (Andreasen \& Stryhn 2008, Goerke et al. 2008). In general, comparison of results from Finland with those of other countries should be done with caution since spring-sown oilseed cultivars predominate in Finland whereas winter oilseeds, with an over-wintering weed flora, are predominant in other countries.

The efficacy of chemical control was relatively good in most of the survey fields. The most commonly used herbicide, trifluralin, did not seem to control the late-emerging and climbing G. spurium effectively enough in all survey fields. As always, the final outcome of weed control is a combination of herbicide efficacy and the competitive ability of the crop, which was not optimal in all fields and particularly not in 2007 when insect pests affected the crop. Farmers obviously recognize the need for controlling $E$. repens because both selective graminicides and glyphosate were commonly used. In reference to the results of our weed survey, henceforth advisory efforts should place greater emphasis on the need for new strategies and options to control certain harmful broad-leaved species. In this respect, launching of new selective herbicide products on the Finnish market would be desirable.

Chenopodium album markedly reduces both the quantity and quality of oilseed yield and should consequently be regarded as one of the main targets of chemical weed control. In this respect, introduc- 
Vol. 20(2011): 262-268.

tion of the clopyralid/picloram product on the Finnish market in 2010 and promising experiences with the CLEARFIELD ${ }^{\circledR}$ production system (Ruuttunen et al. 2010) represent feasible options to replace trifluralin as both effectively control C. album, which was one of the predominant weed species. In addition, both new options improve the control of the perennial broad-leaved species Cirsium arvense and Sonchus arvensis, which were not effectively controlled with trifluralin. It is likely that farmers either place reliance on chemical weed control or leave the oilseed fields untreated instead of choosing mechanical weed control, which has become apparent also in the weed surveys in spring cereal fields (Salonen et al. 2001, Salonen et al. 2011). In general, more sustainable use of herbicides is possible with the new compounds because they can be applied according to observed need after the emergence of weed seedlings, which was not the case with trifluralin, which had to be incorporated into the soil at sowing time.

Plant breeding programmes in Finland have been successful in terms of increasing yield potential and improving chemical composition of oilseed yield. Unfortunately, it seems that the newly released cultivars are targeted for cultivation in highly productive environments but are sensitive to the stressful growing conditions that often occur in Finland. Therefore, the current realistic national potential for spring turnip rapeseed yield is estimated to be around $2100 \mathrm{~kg} \mathrm{ha}^{-1}$, which has actually not been realized during recent years (Peltonen-Sainio et al. 2007). In principle, oilseed crops suppress weed growth efficiently, particularly if the conditions for establishment and early growth are favourable (Beckie et al. 2008). In our survey, one third of the fields rated 'low weed infestation' had not been treated with herbicides. However, the yield levels in weed survey fields, $1550-1850 \mathrm{~kg}$ $\mathrm{ha}^{-1}$, were clearly lower than the above-mentioned potential average yield.

In conclusion, the main weeds of oilseed crop fields were the same as those recorded in earlier surveys of spring cereal and pea fields in Finland. Weeds should be considered as a one of the main constraints to oilseed production, both in terms of yield quantity and quality. Fortunately, the crops are highly competitive under favourable conditions and new options for chemical weed control have been introduced.

Acknowledgements. The weed survey was part of the research project "Improving competitive ability of Finnish oil crop production: enhancing yields and increasing cultivation area (RYPSINOSTE) “, coordinated by Professor Pirjo Peltonen-Sainio. She, Terho Hyvönen and Pentti Ruuttunen provided valuable comments on the manuscript. Lauri Jauhiainen assisted with the statistics. We thank farmers who allowed us to visit their fields and provided us with information about farming practices. Sampling procedure was a joint effort by MTT, Satafood Development Association and Suomen Rehu Ltd. The survey was financed by MTT Agrifood Research Finland, the Ministry of Agriculture and Forestry, Mildola Ltd. and Suomen Rehu Ltd.

\section{References}

Andreasen, C. \& Stryhn, H. 2008. Increasing weed flora in Danish arable fields and its importance for biodiversity. Weed Research 48: 1-9.

Beckie, H.J., Johnson, E.N., Blackshaw, R.E. \& Gan, Y. 2008. Weed suppression by canola and mustard cultivars. Weed Technology 22: 182-185.

Delp, B.R., Stowell, L.J. \& Marois J.J. 1986. Evaluation of field sampling techniques for estimation of disease incidence. Techniques 76: 1299-1305.

FAOSTAT 2011. Agricultural data. Available online at http:// faostat.fao.org/site/567/default.aspx. Accessed 31 January 2011.

Goerke, K., Richter, U., Schulte, M. \& Gerowitt, B. 2008. Regionale Unterschiede in der Rapsunkrautflora Deutschlands. Gesunde Pflanzen 60: 151-158.

Goerke, K., Schönhammer, A., Schulte, M. \& Gerowitt B. 2007. Weeds in oilseed rape in Germany. Status and assessment of changes. Proceedings $14^{\text {th }}$ EWRS Symposium, Hamar, Norway. p. 198.

Peltonen-Sainio, P., Jauhiainen, L. \& Hannukkala, A. 2007. Declining rapeseed yields in Finland: how, why and what next? Journal of Agricultural Science 145: 587-598.

Peltonen-Sainio, P., Jauhiainen, L., Laitinen, P., Salopelto, J., Saastamoinen, M. \& Hannukkala, A. 2011. Identifying difficulties in rapeseed root penetration in farmers' fields in northern European conditions. Soil Use and Management 27: 229-237.

Peltonen-Sainio, P., Jauhiainen, L. \& Venäläinen, A. 2009. Comparing regional risks in producing turnip rape and 


\section{AGRICULTURAL AND FOOD SCIENCE}

Salonen, J. et al. Weeds in oilseed crops in Finland

oilseed rape - Today in light of long-term datasets. Acta Agriculturae Scandinavica Section B - Soil and Plant Science 59: 118-128.

Ruuttunen, P., Lassi, K. \& Pfenning, M. 2010. Effective weed control in spring turnip rape (Brassica rapa subsp. oleifera) using the CLEARFIELD ${ }^{\circledR}$ production system. Proceedings of the $15^{\text {th }}$ EWRS Symposium, Kaposvár Hungary. p. 297-298.

Salonen, J., Hyvönen, T. \& Jalli, H. 2001. Weeds in spring cereal fields in Finland - a third survey. Agricultural and Food Science in Finland 10: 347-364.
Salonen, J., Hyvönen, T. \& Jalli, H. 2005. Weed flora and weed management of field peas in Finland. Agricultural and Food Science 14: 189-201.

Salonen, J., Hyvönen, T. \& Jalli, H. 2011. Composition of weed flora in spring cereals in Finland - a fourth survey. Agricultural and Food Science 20:p. 245-261.

TIKE 2010. Matilda Agricultural Statistics service. Available online at: http://www.maataloustilastot.fi/en/utilisedagricultural-area. Accessed 10 Febuary 2011.

Týr, S. \& Vereš, T. 2010. Temporal dynamics of weed infestation in the winter oilseed rape canopies. Herbologia 11, No. 2: 1-8. 